\title{
MOLECULAR CHARACTERIZATION OF A DUCK VIRUS HEPATITIS ISOLATE ISOLATED FROM SHARKIA GOVERNORATE.
}

\author{
BAYOUMIE, H.A.A. ${ }^{*}$ and ABD EL-SAMIE, L.K ${ }^{* *}$ \\ *Animal Health Res. Inst. Zagazig (Poult. Dis. Dept.) \\ *** (Vet. Hospital) Facult. Vet. Med. Zagazig Univ.
}

\section{ABSTRACT}

Received at: $27 / 8 / 2015$

Accepted: 17/9/2015
In the present study a Blencher duckling flock with $70 \%$ recurrent mortality on each reared batch was examined for the cause of mortality. live duckling were showing nervous signs and opisthotonos, sacrificed samples revealed depressed areas on the liver marking the large blood vessels while Hemorrhagic lesion suggestive for DVH were only noticed on liver of dead duckling carcasses. Liver samples were collected for virus isolation trials and for immunofluorescence. Initial virus isolation in embryonated chicken eggs ECE after ultra-filtration through $400 \mathrm{~nm}$ membrane filter revealed small size hemorrhagic edematous embryos this lesion was consistent upon a series of ultra-membrane filtration through 200 and $100 \mathrm{~nm}$ membrane filters which indicate a Picorna virus. Immunofluorescence examination revealed positive results for duck virus hepatitis (DVH). Clinical samples examined by generic RTPCR assays followed by partial sequence analysis of the $3 \mathrm{D}$ gene revealed that the isolate was characterized as Duck hepatitis A virus resembling the strain (DHV/Duck / Egypt / Al-Gharbia /2014) in the 3D protein gene whom its gene bank accession number was (KP202874). The current study stresses on the value of ultramembrane filtration through a $100 \mathrm{~nm}$ membrane filters as a rapid diagnostic tool For DVH without the need for extra laboratory diagnostic work. Interpretation of sequence results revealed that. The isolated (DVH/EG. Bayoumieh-Sharkia-2015) is a Duck hepatitis type A virus. With $100 \%$ resemblance to the strain (DHV/Duck/ AlGharbia /2014) Egypt/ in 3D protein gene with gene bank accession number (KP202874) unpublished data. Sequence and phylogenetic analysis indicated that the (DVH/EG. Bayoumieh-Sharkia-2015) isolate is clustered in the DHAV serotype 1 but was distinguishable from the other isolated Egyptian strains with resemblance ranging between $63.1-63.8 \%$.

Key words: DVH-A, Fluorescence, Ultra membrane filtration, (DVH/EG. Bayoumieh-Sharkia-2015), Picornavirus, Ducklings, Egypt,RT-PCR, sequencing

\section{INTRODUCTION}

Duck virus hepatitis (DVH) is a highly fatal rapidly spreading viral infection of young ducklings, characterized primarily by hepatitis. The disease constitutes a great economic importance to all duck growing farms because of the high potential mortality if not controlled. The disease is caused by at least three different viruses Woolcock and Tsai (2013).

The most pathogenic DVH is a member of the newly proposed Picornavirus genus (Avihepatovirus) duck hepatitis A virus 1 (DHAV-1), formerly designated as duck hepatitis virus type 1 or DHV-1 (Levine and Fabricant (1950) followed by many authers \{Asplin (1965), Calnek (1993), Kim et al. (2006), Ding and Zhang (2007)\}.
DHAV-2 isolated in Taiwan by Tseng and Tsai (2007), and DHAV-3 isolated in South Korea by Kim et al. (2007), and in China by Fu et al. (2009) are two newly described DHV genotypes, belongs to the same proposed Avihepatovirus genus; they can also cause high mortality in ducklings.

DHAV-2 and DHAV-3 were first recognized as separate entities because they induced hepatitis in DHAV-1-immune ducklings Asplin (1965), Toth (1969), Haider and Calnek (1979), Calnek (1993), Gough et al. (1984), Gough et al. (1985), Gough and Stuart (1993), Monroe et al. (2005), Todd et al. (2009), Fu et al. (2009). These two viruses are now reclassified and named as Duck Astrovirus types 1 and 2, respectively Fu et al. (2009). 


\section{MATERIALS}

\section{Samples}

Twenty thousand 7-day-old Blanchard ducklings reared in Belbees Sharkia., expressing $70 \%$ mortality was the subject for our investigation. Affected ducklings were showing nervous signs and opisthotonos (fig - 1).

Embryonated chicken eggs (ECE):

Nine day old ECE were used for DVH isolation trials according to levine and Fabricant (1950), OIE (2010).

\section{Membrane filters}

$450 \mathrm{~nm}$ Thermo scientific Nalgene syringe filter. Catno. 190-2545 (8-0404-40493), $200 \mathrm{~nm}$ Thermo scientific syringe filter. Nalgene cat. no. 190-2520 (80404-391109). $100 \mathrm{~nm}$ Sigm Aldrich syringe filter cat. no. (f-7523).

\section{RT-PCR RNA extraction}

QIAamp Viral RNA Mini kit (Qiagen, Germany, $\left.\mathrm{GmbH}^{\circledR}\right)$.

\section{Duck virus hepatitis vaccinal strain}

Vaccinal strain of \{VAC Sera Abbasia kindly obtained from Prof. Dr. Susan Tolba (Head of poult. Vaccine unit)\}.

\section{Duck virus hepatitis Antiserum.}

Anti-duck virus hepatitis produced in rabbits, against the vaccinal strain of VAC Sera Abbasia.

\section{Preparation of duck virus hepatitis Antiserum.}

Anti-duck virus hepatitis serum produced in rabbits using vaccinal strain of DVH was used in immunoflourescent antibody technique (IFAT) according to Hanaa et al. (2013).

\section{METHODS}

\section{Sample preparation for ECE inoculation}

Livers of necropsied ducklings showing hemorrhages were homogenized and subjected for three successive freeze-thaw cycles, then $1 / 10$ suspension was made of it. The suspension was clarified by centrifugation for $10 \mathrm{~min}$ at $3000 \mathrm{rpm}$ OIE (2010). Initial sample was filtered through $450 \mathrm{~nm}$ filter for bacterial sterility. Part of allantoic fluid (AF) from the first passage was filtered through $200 \mathrm{~nm}$ filter; another part was filtered through $100 \mathrm{~nm}$ filter, these were further used for ECE inoculation.

\section{RNA extraction}

RNA extraction from the supernatant of liver homogenates were performed using the QIAamp Viral RNA Mini kit (Qiagen, Germany, $\mathrm{GmbH}^{\circledR}$ ) according to their manufacturer's recommendations. The RTPCR assays using oligo-nucleotide primers specific to the sequence coding for the $3 \mathrm{D}$ protein. Primers designated DHV-1 ComF (5'-AAG AAG GAG AAA ATY (C or T) AAG GAA GG-3') and DHV-1 ComR (5'- TTG ATG TCA TAG CCC AAs (c or G) ACA GC-3') flank a 467 base pair DNA in the 3D gene as indicated by OIE (2010) was used.

Partial amplification of 3D genes were conducted as performed by Erfan et al. (2015). The reactions were performed in a T3 thermo cycler (Biometra ${ }^{\circledR}$ ). The amplicons were separated by electrophoresis on $1.5 \%$ agarose gel (Applichem, Germany, GmbH) along with 100- bp DNA Ladder (Qiagen, Germany, $\left.\mathrm{GmbH}^{\circledR}\right)$. The gel was photographed by a gel documentation system (Alpha Innotech, Biometra) and the data were analysed by a computer software (Automatic Image Capture Software, Biosciences, $\left.\mathrm{USA}^{\circledR}\right)$.

\section{Sequence and phylogenetic analyses}

Partial sequence of the 3D gene of the field isolate was generated using forward and reverse primers of the generic PCRs, Amino acid sequences were deduced from the generated nucleotides using BioEdit software version 7.1.7 Hall (1999). Sequences of query and representative DVH was retrieved from the GenBank database. All sequences were aligned and identity matrices were calculated automatically using BioEdit. Phylogenetic analyses using maximum likelihood, neighbour joining and maximum parsimony in MEGA6 Tamura et al. (2013). Consensus unrooted trees were generated with 100 bootstrap replicates and were further edited using Inkscape 0.91 (Free Software Foundation, Inc., USA).

\section{RESULTS}

Results of the present study is shown in table (1-2) and figures (1-9).

Table 1: shows the partial sequence analysis of 3 D gene of the (DVH/EG.Bayoumieh-Sharkia-2015).

TGAGATAGTATGCAGCTGATCCAATTGAGTTTAGGACAGTAGTGCATGGTGACCCTGAGCACATAC CGCCTTCCACCTTCCAAATCTCATCAGTGACATAGTGTGTTGAATAGATGGTTGGCTCATGAATTTT CTTCACAAGGGCTGGATCGTTATGGAAAAATGACAACACATCAACAGCTTCTTCCAAAATTTGAGC ACTCAGAGACCCGTCAAAACCAGAAAAGTCCAAACACAAGTTGTAGGGCTGCAGATTTGCTAACA GATTGTCCCACTCGGCAAAAGGGTTGATTCCAACAGCACAGCCTGATAGAATAAAGCTGTCATCAT AAATGTTGGAATAAATTTCACCCATAACCATGCGGAACGCAACTGTGTAGTCAAAGTTGCATGCCT CAATACCTCGAGTCTTTCCTTCCTT 
Table 2: Nucleotide (upper right) and amino acid (lower left) of (DVH/EG.Bayoumieh-Sharkia-2015) 3D gene compared to the Egyptian isolates of Erfan et al. (2015).

\begin{tabular}{|c|c|c|c|c|c|c|c|c|c|c|c|c|c|c|c|c|c|c|c|}
\hline \multicolumn{20}{|c|}{ Percent Identity } \\
\hline & 1 & 2 & 3 & 4 & 5 & 6 & 7 & 8 & 9 & 10 & 11 & 12 & 13 & 14 & 15 & 16 & 17 & & \multirow[b]{2}{*}{ KP148263 } \\
\hline 1 & & 96.8 & 96.8 & 96.8 & 96.8 & 96.8 & 97.0 & 96.8 & 96.8 & 96.8 & 96.3 & 96.8 & 96.8 & 96.8 & 96.3 & 96.8 & 63.1 & 1 & \\
\hline 2 & 4.5 & & 100.0 & 100.0 & 100.0 & 100.0 & 99.8 & 100.0 & 100.0 & 100.0 & 98.8 & 100.0 & 100.0 & 100.0 & 98.8 & 100.0 & 63.8 & 2 & KP148264 \\
\hline 3 & 4.5 & 0.0 & & 100.0 & 100.0 & 100.0 & 99.8 & 100.0 & 100.0 & 100.0 & 98.8 & 100.0 & 100.0 & 100.0 & 98.8 & 100.0 & 63.8 & 3 & KP148265 \\
\hline 4 & 4.5 & 0.0 & 0.0 & & 100.0 & 100.0 & 99.8 & 100.0 & 100.0 & 100.0 & 98.8 & 100.0 & 100.0 & 100.0 & 98.8 & 100.0 & 63.8 & 4 & KP148266 \\
\hline 5 & 4.5 & 0.0 & 0.0 & 0.0 & & 100.0 & 99.8 & 100.0 & 100.0 & 100.0 & 98.8 & 100.0 & 100.0 & 100.0 & 98.8 & 100.0 & 63.8 & 5 & KP148267 \\
\hline 6 & 4.5 & 0.0 & 0.0 & 0.0 & 0.0 & & 99.8 & 100.0 & 100.0 & 100.0 & 98.8 & 100.0 & 100.0 & 100.0 & 98.8 & 100.0 & 63.8 & 6 & KP148268 \\
\hline 7 & 4.2 & 0.2 & 0.2 & 0.2 & 0.2 & 0.2 & & 99.8 & 99.8 & 99.8 & 99.0 & 99.8 & 99.8 & 99.8 & 99.0 & 99.8 & 63.6 & 7 & KP148269 \\
\hline 8 & 4.5 & 0.0 & 0.0 & 0.0 & 0.0 & 0.0 & 0.2 & & 100.0 & 100.0 & 98.8 & 100.0 & 100.0 & 100.0 & 98.8 & 100.0 & 63.8 & 8 & KP148270 \\
\hline 9 & 4.5 & 0.0 & 0.0 & 0.0 & 0.0 & 0.0 & 0.2 & 0.0 & & 100.0 & 98.8 & 100.0 & 100.0 & 100.0 & 98.8 & 100.0 & 63.8 & 9 & KP148271 \\
\hline 10 & 4.5 & 0.0 & 0.0 & 0.0 & 0.0 & 0.0 & 0.2 & 0.0 & 0.0 & & 98.8 & 100.0 & 100.0 & 100.0 & 98.8 & 100.0 & 63.8 & 10 & KP148272 \\
\hline 11 & 5.2 & 1.6 & 1.6 & 1.6 & 1.6 & 1.6 & 1.4 & 1.6 & 1.6 & 1.6 & & 98.8 & 98.8 & 98.8 & 100.0 & 98.8 & 63.8 & 11 & KP148273 \\
\hline 12 & 4.5 & 0.0 & 0.0 & 0.0 & 0.0 & 0.0 & 0.2 & 0.0 & 0.0 & 0.0 & 1.6 & & 100.0 & 100.0 & 98.8 & 100.0 & 63.8 & 12 & KP148274 \\
\hline 13 & 4.5 & 0.0 & 0.0 & 0.0 & 0.0 & 0.0 & 0.2 & 0.0 & 0.0 & 0.0 & 1.6 & 0.0 & & 100.0 & 98.8 & 100.0 & 63.8 & 13 & KP148275 \\
\hline 14 & 4.5 & 0.0 & 0.0 & 0.0 & 0.0 & 0.0 & 0.2 & 0.0 & 0.0 & 0.0 & 1.6 & 0.0 & 0.0 & & 98.8 & 100.0 & 63.8 & 14 & KP148276 \\
\hline 15 & 5.2 & 1.6 & 1.6 & 1.6 & 1.6 & 1.6 & 1.4 & 1.6 & 1.6 & 1.6 & 0.0 & 1.6 & 1.6 & 1.6 & & 98.8 & 63.8 & 15 & KP148277 \\
\hline 16 & 4.5 & 0.0 & 0.0 & 0.0 & 0.0 & 0.0 & 0.2 & 0.0 & 0.0 & 0.0 & 1.6 & 0.0 & 0.0 & 0.0 & 1.6 & & 63.8 & 16 & KP148278 \\
\hline \multirow[t]{2}{*}{17} & 26.9 & 25.4 & 25.4 & 25.4 & 25.4 & 25.4 & 25.8 & 25.4 & 25.4 & 25.4 & 25.4 & 25.4 & 25.4 & 25.4 & 25.4 & 25.4 & & 17 & \multirow[t]{2}{*}{ DVH-EG-Boyoumieh-shorkio } \\
\hline & 1 & 2 & 3 & 4 & 5 & 6 & 7 & 8 & 9 & 10 & 11 & 12 & 13 & 14 & 15 & 16 & 17 & & \\
\hline
\end{tabular}

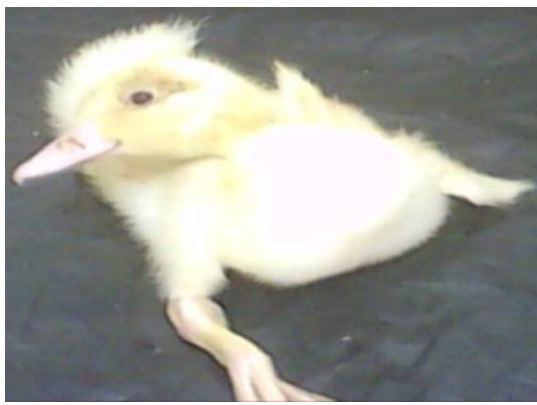

Fig. 1: A young duckling that is Showing opisthotonos

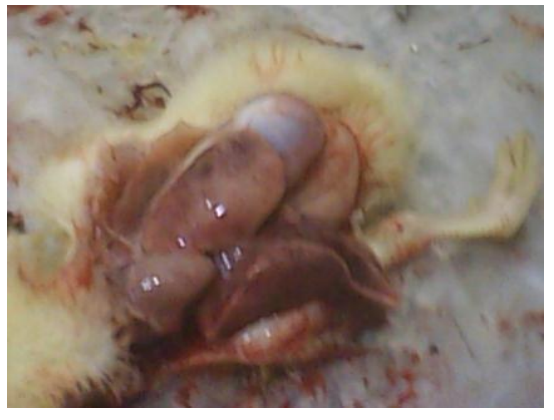

Fig. 3: Young duckling showing typical liver hemorrhagic lesions of duck virus hepatitis

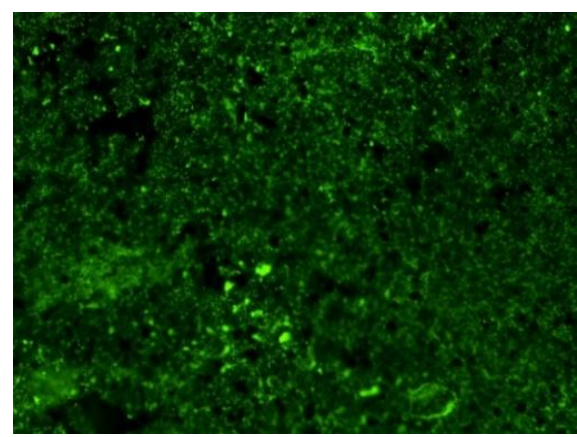

Fig.5: Liver smears from 7 ds old duckling stained with antirabbit IgG conjugated with FITC for DVH. Mark the fluorescence in the infected hepatocytes X 400 .

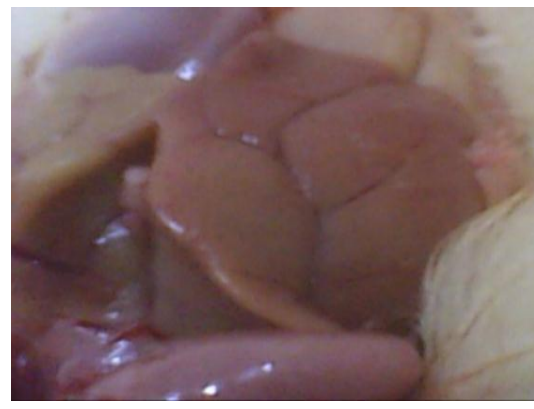

Fig. 2: shows liver of sacrificed ducklings had depressed areas marking large blood vessel

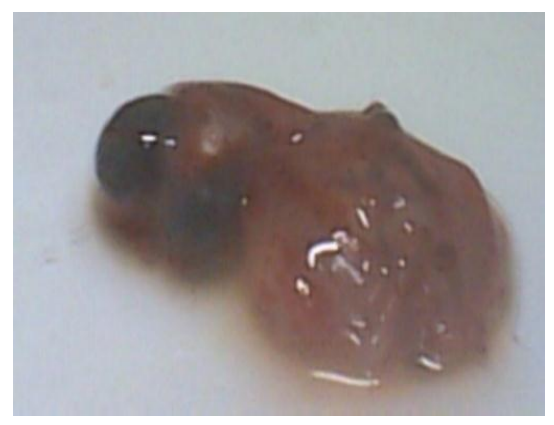

Fig.4: 13 day old chicken embryo was inoculated at 9 days with $100 \mathrm{~nm}$ filtrate of the A.S. fluid. Note the small size, hemorrhage, and edema.

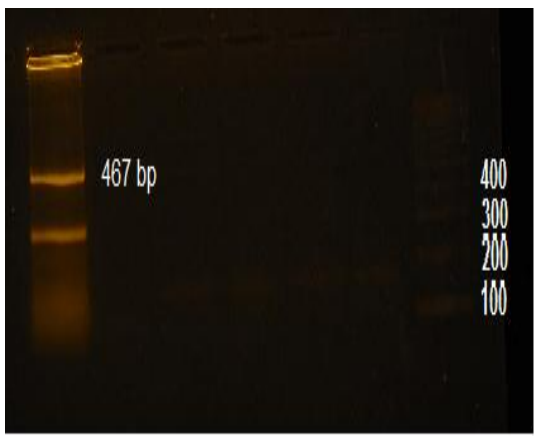

Fig. 6: Shows PCR. Lane 467 bp using a ladder of 100 bp for (DVH/EG.Bayoumieh-Sharkia-2015). 
Fig. 7: showing phylogenetic tree of (DVH/EG.Bayoumieh-Sharkia-2015) compared to the Egyptian isolates of Erfan et al. (2015).

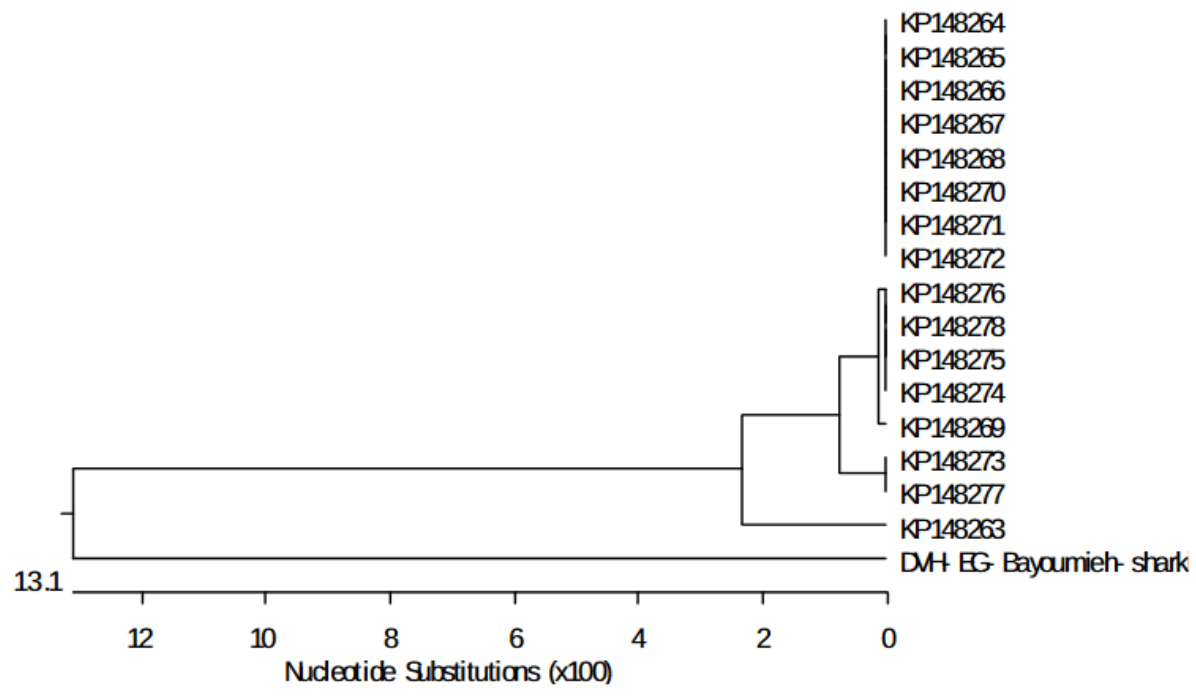

Fig. 8: Nucleotide Alignment (DVH/EG. Bayoumieh-Sharkia-2015) compared to the Egyptian isolates of Erfan et al. (2015).

\begin{tabular}{|c|}
\hline Hojojorly \\
\hline KP 148265J \\
\hline KP 148264 \\
\hline KP 148265 \\
\hline KP 1482666 \\
\hline KP 148267 \\
\hline KP 148268 \\
\hline KP 148269 \\
\hline KP 148270 \\
\hline KP 148271 \\
\hline KP 148272 \\
\hline KP 14827J \\
\hline KP 148274 \\
\hline KP 148275 \\
\hline KP 148276 \\
\hline KP 148277 \\
\hline KP 148270 \\
\hline
\end{tabular}

Mojorily

KP 140263

KP 148264

KP 148265

KP 148266

KP 148267

KP 148268

KP 148269

KP 148270

KP 148271

KP 148272

KP 148275

KP 148274

KP 142275

KP 140276

KP 148277

KP 148278

DWH-EG-Boyoumieh-shorkio

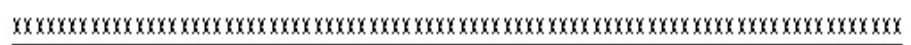

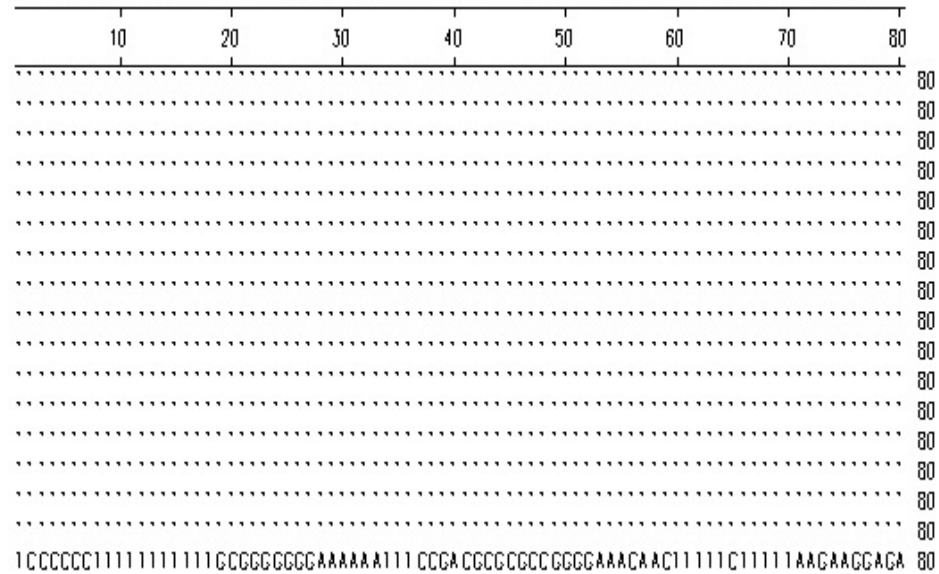

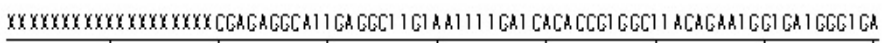

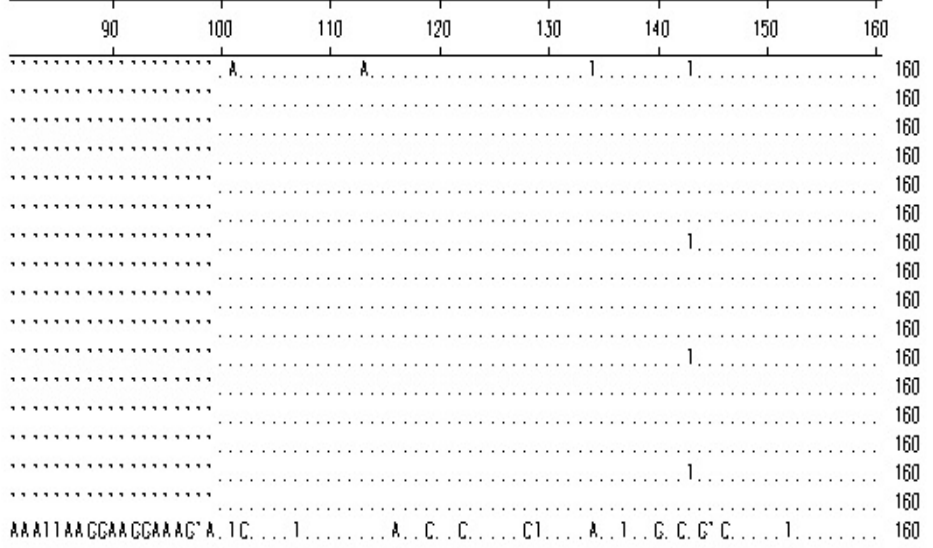


$\underline{\text { Assiut Vet. Med. J. Vol. } 61 \text { No. } 147 \text { October } 2015}$

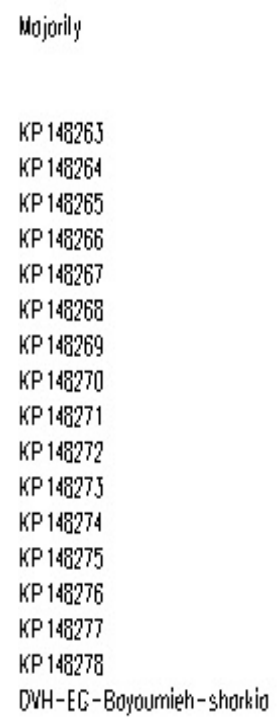

Mojorily

KP 148263

KP 148264

K.P 148265

KP 148266

K.P 148267

KP 148260

KP 148269

KF 148270

KF 148271

KP 148272

KP 14827,

KP 148274

KP 148275

KP 148276

KP 140277

DWH-EG-Boyoumieh-shorkio

Mojorily

KF 148265

KF 148264

KF 148265

K.P 14 18266

KP 14826?

K.P 148260

KP 148269

KP 148270

K.P 148271

KP 148272

KF 148275

KP 148274

KF 148275

K.P 140276

KF 148277

K.P 148270

DWH-EG-Boyoumieh-shorkio

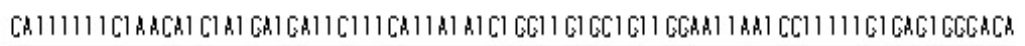

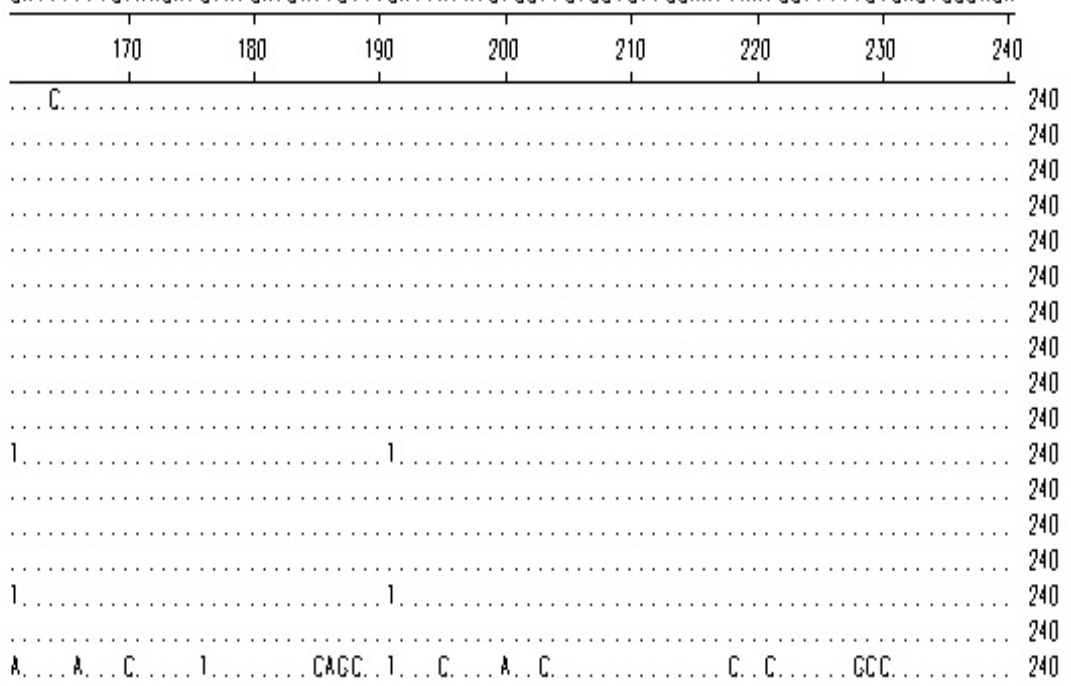

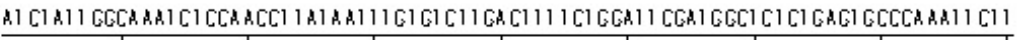

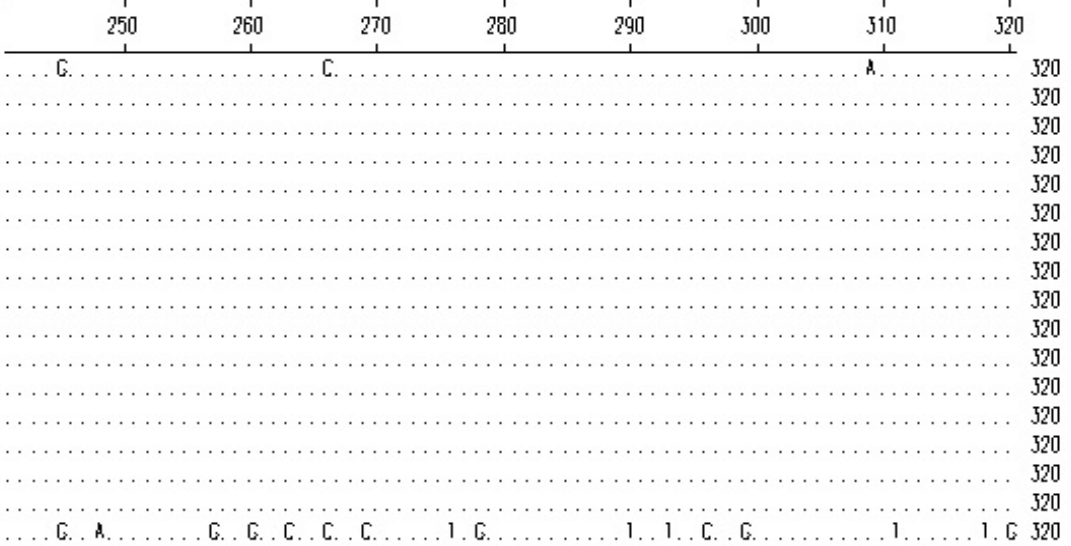

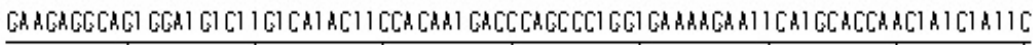

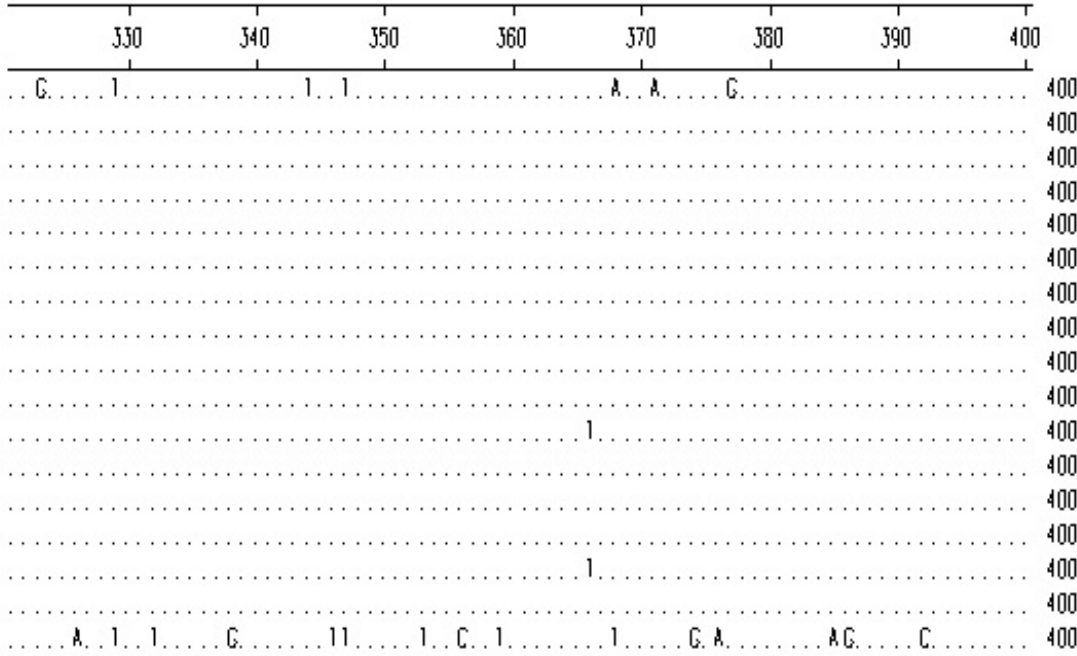


$\underline{\text { Assiut Vet. Med. J. Vol. } 61 \text { No. } 147 \text { October } 2015}$

Mojorily
KP 148265
KP 148264
KP 148265
KP 148266
KP 1482267
KP 148260
KP 148269
KP 148270
KP 148271
KP 148272
KP 148275
KP 148274
KP 148275
KP 148276
KP 148277
KP 148278
DVH-EG-Boyoumieh-shorkio

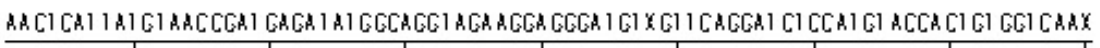

\begin{tabular}{|c|c|c|c|c|c|c|c|c|}
\hline 410 & 420 & 450 & 440 & 450 & 460 & 470 & & \\
\hline$\ldots \ldots \ldots$ & $\ldots$ & $\ldots$ & $\ldots$ & & $\ldots$ & $\ldots$ & & 480 \\
\hline$\ldots \ldots \ldots$ & $\ldots$ & & $\cdots$ & & & & & 480 \\
\hline$\ldots \ldots \ldots \ldots$ & $\ldots$ & $\ldots$ & $\ldots$ & & $\cdots$ & $\ldots$ & & 480 \\
\hline . & & & & & & & & 480 \\
\hline$\ldots \ldots \ldots \ldots$ & & & & & & & & 480 \\
\hline$\cdots$ & $\cdots$ & $\ldots$ & $\cdots$ & & $\therefore$ & & & 480 \\
\hline$\cdots$ & $\cdots$ & $\cdots$ & $\cdots$ & & & & & 480 \\
\hline$\ldots \ldots \ldots$ & $\cdots$ & $\ldots$ & & & & & & 480 \\
\hline$\ldots \ldots$ & $\cdots$ & $\ldots$ & $\cdots$ & & $\cdots$ & & & 480 \\
\hline$\cdots$ & & & & & & & & 400 \\
\hline$\cdots$ & & & & & C. & & & 480 \\
\hline & & & & & & & & 480 \\
\hline & & & & & & & & $\begin{array}{l}400 \\
480\end{array}$ \\
\hline & & & & & C. & & & 480 \\
\hline A. С. . & & A. . & . C. & . C. & A. . & 1 1... & . . & 480 \\
\hline
\end{tabular}

Mojorily

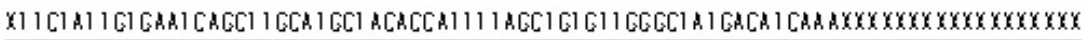

\begin{tabular}{|c|}
\hline KP 14826.5 \\
\hline KP 148264 \\
\hline KP 148265 \\
\hline KP 1482866 \\
\hline KP 148267 \\
\hline KP 148260 \\
\hline KP 1482609 \\
\hline KP 148270 \\
\hline KP 148271 \\
\hline KP 148272 \\
\hline KP 148275 \\
\hline KP 148274 \\
\hline KP 148275 \\
\hline KP 148276 \\
\hline KP 148277 \\
\hline KP 148278 \\
\hline
\end{tabular}

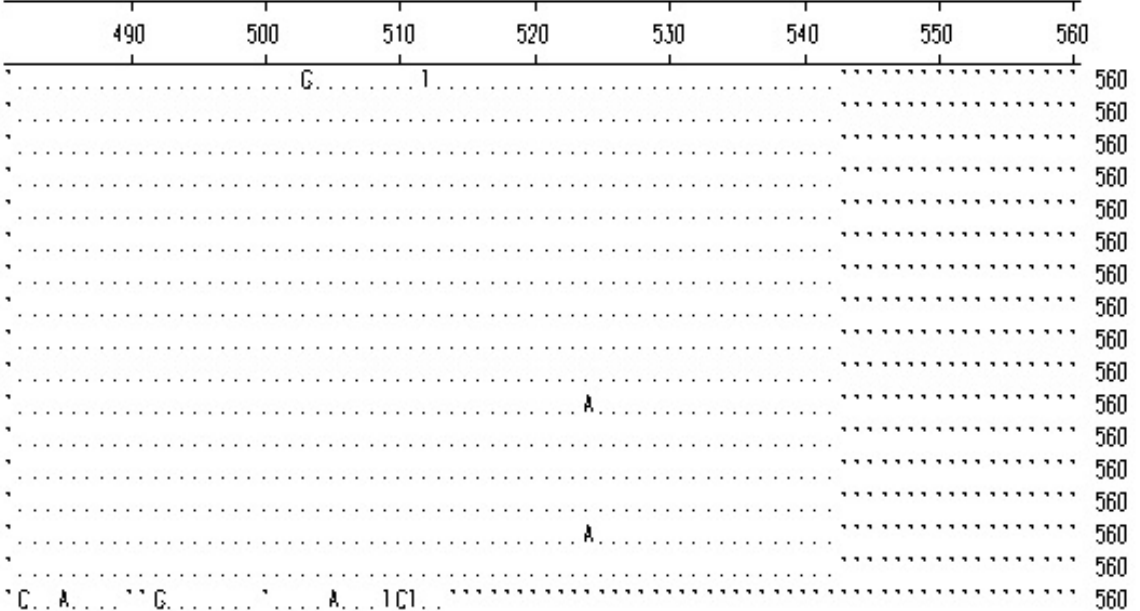

Wojorilly

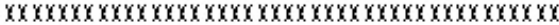

KP 148265

KP 148264

KP 148265

KP 148266

KP 148267

K. 148268

KP 148269

K.P 148270

KP 148271

K.P 148272

KP 148275

KP 148274

K.P 148275

KP 148276

KP 148277

KP 140278

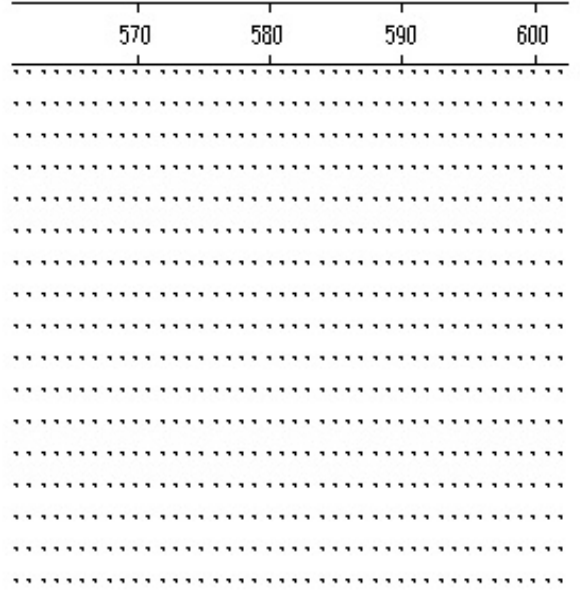

602

602

602

602

602

602

602

602

602

602

602

602

602

602

DVH-EG-Boyoumieh-shork io

602

Decoration Decoration \#1": Hide (as '.) residues that match the Consensus exactly. 
$\underline{\text { Assiut Vet. Med. J. Vol. } 61 \text { No. } 147 \text { October } 2015}$

Fig 9: Shows Amino acid sequence of (DVH/EG. Bayoumieh-Sharkia-2015) compared to the Egyptian isolates of Erfan et al. (2015).

Wojorily

KP 148265

KP 148264

KP 140265

KP 1480266

KP148026?

KP 148260

KP 148269

KP 148270

KP 148271

K.P 148272

KP 148275

KP 148027

KP 148275

KP 148276

KP 148277

KP 148278

DWH-EG-Boyoumieh-shorkio

Mojorily

KP 14826.

KP 14826

K.P 148265

KP148266

KP 14826?

K.P 148260

KP1418260

KP 148270

K.P 14827

KP 148272

KP 14827J

KP 148274

K.P 1410275

KP 148276

KP 14827?

KP 148270

DVH-EG-Boyoumieh-shork io

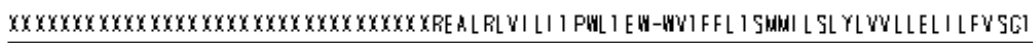

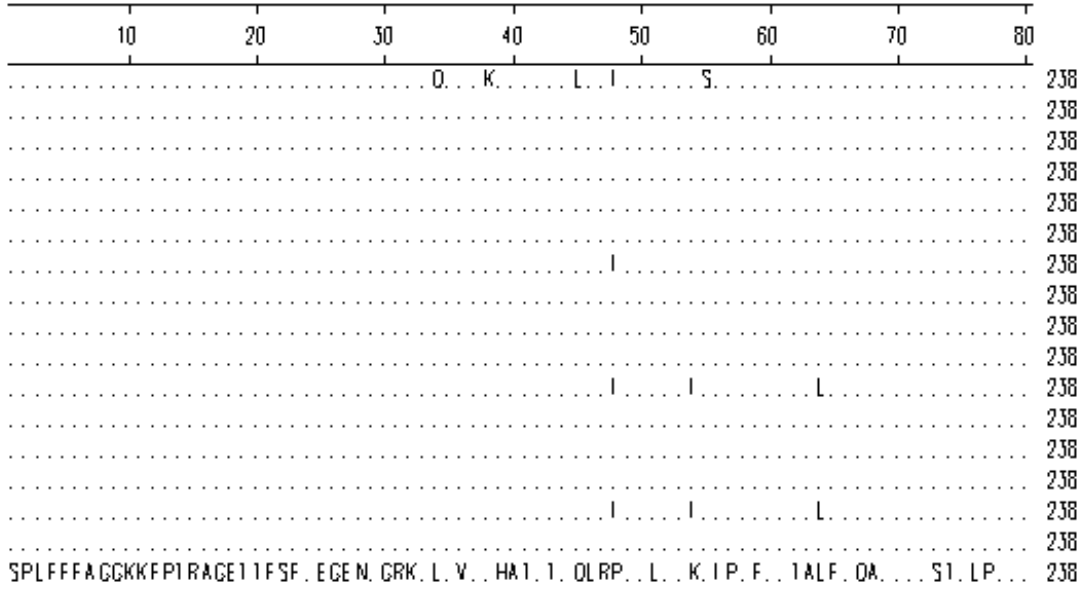

I Y HOI SNLI I CVL I F L DSWAL -VPKFL KROWWSCHI SI WI OPH-KEF WHOL SI OLI W-PWRYGR-KEGCXSCS PCI I WVX

\begin{tabular}{cccccccc}
90 & 100 & 110 & 120 & 150 & 140 & 150 & 160 \\
\hline & 1 & 1 & 150 & 1
\end{tabular}

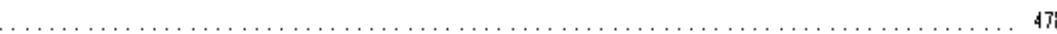

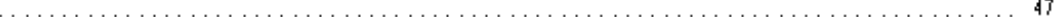

.

.

478

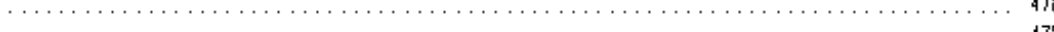

$\ldots \ldots \ldots \ldots \ldots \ldots \ldots \ldots \ldots$

470

.

$\ldots \ldots$

470

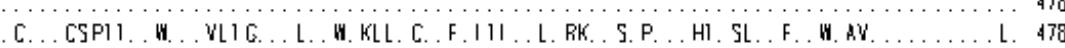

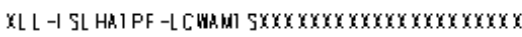

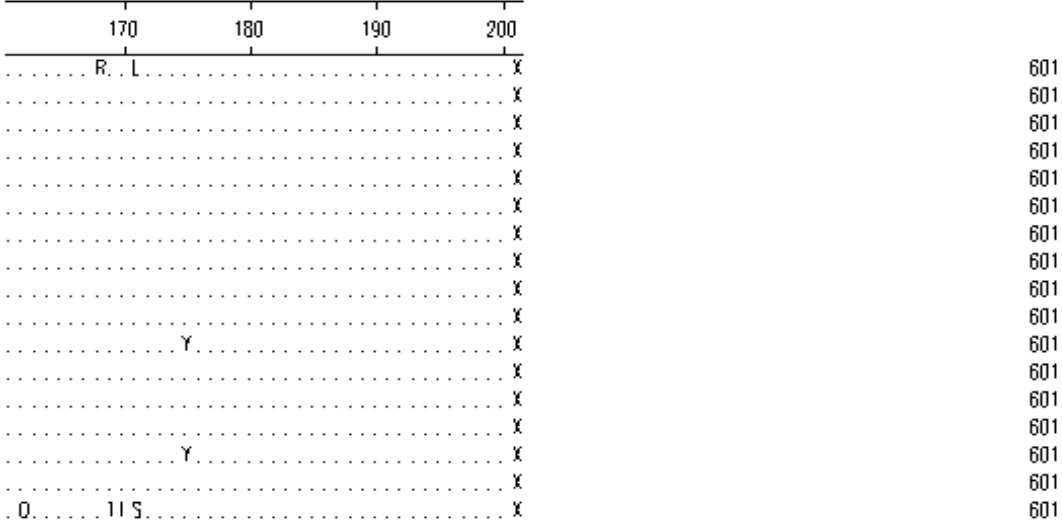




\section{DISCUSSION}

Duck virus hepatitis was first described in 1950, causing severe losses in ducklings in Long Island, New York, then spread to the major duck-growing area of the USA, and ever since It has been described in most important duck-growing areas of the world. The disease has usually become endemic in these regions. The disease is an acute, highly infectious viral disease of ducklings aged from 2 days to 3 weeks. Older ducklings may be diseased, particularly if affected by toxic substances or suboptimal nutrition, but adult stock are resistant. Age resistance to disease is essentially complete from 7 weeks of age Woolcock (2003).

Gough and McNutly (2008) mentioned that Signs of DVH- I infection are per acute., death usually follows within an hour of their onset. Affected birds are often in good condition but start to lose contact with the main flock. Soon they fall over on their sides and, after a short struggle, with paddling movements of the legs, the birds die. The head is usually stretched upwards and backwards (opisthotonos). The mortality rate may be over $90 \%$ of the flock. In the present study examined ducklings were showing nervous signs and opisthonous as seen in (fig-1) with a history of $70 \%$ mortality until they were delivered to the lab.

The main lesions appear in the liver as mentioned by Gough and McNutly (2008) is liver enlargement with a number of petechial and ecchymotic hemorrhages. In addition, fatty kidneys described as duck fatty kidney syndrome may be caused by DVHV. In the present study PM of the sacrificed samples revealed depressed areas on the liver surface marking the large blood (fig-2). Hemorrhagic lesion of DVH was only noticed in dead duckling carcasses (fig-3).

The sudden onset of a disease., the high mortality in young ducklings, the opisthotonos of the bird and, the characteristic liver hemorrhages are together pathognomonic and sufficient to justify the diagnosis of DVH But the Occurrence of similar disease outbreaks caused by serologic variants of DHAV-1, 2 and -3 are the main problem in differential diagnosis and the need for laboratory diagnosis is raised for legislative purposes.

Woolcock (2008) and Woolcock (2010). Mentioned that the presence of DVH may be confirmed by many Laboratory procedures. Diagnosis of type I virus infection is based on virus isolation following the inoculation of organ suspension from affected ducklings into the allantoic sac of 9-day-old ECE or 10 to 14 day EDE. Levine and Fabricant (1950) were the first to propagate the virus in the allantoic sac of 9-day-old chicken embryos. $10-60 \%$ of the embryos died by the $5^{\text {th }}$ or $6^{\text {th }}$ day and were stunted or edematous. In the present study virus isolation was attempted by inoculation of $1 / 10$ dilution of liver suspension filtered through a $450 \mathrm{~nm}$ filter into 9 day old ECE through the allantoic cavity according to the standard protocol of OIE (2010). Eggs were candled daily for up to 6 days. Inoculated embryos showed stunting and subcutaneous hemorrhages over the whole body with edema, particularly of the abdominal and hind limb regions (fig. 4). The embryo livers may be swollen, red, in color, and show necrotic foci. The liver lesions and embryo stunting become more apparent in embryos that took longer time to die. The Collected allantoic fluid was filtered through $200 \mathrm{~nm}$ and $100 \mathrm{~nm}$ membrane filter and used again for another inoculation ECE. Which revealed hemorrhagic edematous embryos (fig-4). Ultrastructure, Size, Density, Symmetry of DHAV-1 is naked virus with an icosahedral capsid and has been estimated to be 20-40 nm in size Reus (1959), Richter et al. (1964), Tauraso et al. (1969) which is a typical picornavirus morphology.

Rapid diagnosis using direct immunofluorescence may be made on the livers of affected ducklings Woolcock and Tsai (2013), Maiboroda (1972), Vertinskii et al. (1968). In the present study an impression smears were prepared from tissues taken from field samples ., these smears were stained using rabbit anti-duck hepatitis poly clonal serum and an anti-rabbit IF conjugate \{Vertinskii et al. (1968), Maiboroda (1972), and Hanaa et al. (2013)\}. Positive results were recorded as showen (fig-5).

Woolcock and Tsai (2013) mentioned that during Differential Diagnosis The sudden onset, rapid spread, and acute course of the disease caused by DHAV-1 are characteristic, and the hemorrhagic lesions in liver of ducklings up to 3 weeks of age are pathognomonic. Occurrence of similar disease outbreaks caused by serologic variants of (DVH) -1, 2 and -3 are the main problem in differential diagnosis. Gough and Wallis (1986) reported the association of DVH -1 with influenza virus in 2- to 5week-old mallard ducks reared on a game farm. The DVH -1 isolated was of low virulence, and it is suggested that the influenza virus may have exacerbated the hepatitis infection. Other potential causes of acute mortality in ducklings include salmonellosis and aflatoxicosis. The latter disease may cause ataxia, convulsions, and opisthotonos as well as microscopic lesions of bile duct hyperplasia suggestive of DVH, but does not cause the same characteristic liver hemorrhages. None of the other common lethal diseases of ducks occur frequently in this young age group.

Several reverse transcriptase polymerase chain reactions (RT-PCR) have been developed and are useful for identifying DHAV -1 infection such as Kim et al. (2007), Cheng et al. (2009). Fu et al. (2008) reported the detection limit of RT-PCR for 
DHAV $-1 \quad$ RNA as $3 \quad \mathrm{pg} / 10 \mu \mathrm{l}$. They also demonstrated that RT-PCR was the most sensitive when the detection rates were compared on 185 clinically suspected DHAV -1-infected liver tissues by RT-PCR, ELISA, and virus isolation methods. Rapid and specific detection of the DHAV RNA using different RT-PCR assays were described Fu et al. (2008), Liu et al. (2008), OIE (2010) and Wei et al. (2012).

Molecular techniques have been described for the detection of DHAVH -1 in clinical material. Sequence results for our examined sample are shown in (fig-7). Interpretation of sequence revealed that The investigated Sample (DVH/EG. BayoumiehSharkia-2015) is a Duck hepatitis A virus. With $100 \%$ resemblance to the strain (DHV/Duck/Egypt/AlGharbia/2014) in 3D protein gene with gene bank accession number (KP202874) Sultan, and Talaat, (2014) unpublished data. Sequence and phylogenetic analyses also indicated that the (DVH/EG. Bayoumieh-Sharkia-2015) isolate cluster in the DHAV - 1 and was distinguishable from the Egyptian strains of Erfan et al. (2015) with a resemblance \% ranging between (63.1-63.8\%) (table -2, fig - 8).

\section{ACKNOWLEDGMENTS}

The author is grateful to his colleagues at NLQP and Poult. Dis. Dept. AHRI

\section{REFERENCES}

Asplin, F.D. (1965): DVH: vaccination against two serological types. Vet Rec. 77:1529-1530.

Calnek, B.W. (1993): Duck virus hepatitis. In: Virus infections of Birds, Vol. 4. J.B. McFerran and M.S. McNulty, eds. ElsevierScience Publishers B. V., Amsterdam. 485-495.

Cheng, A.; Wang, M.; Xin, H.; Zhu, D.; Li, X.; Chen, H.; Jia, R. and Yang, M. (2009): Development and application of a reverse transcriptase polymerase chain reaction to detect Chinese isolates of duck hepatitis virus type 1. J. Microbiol Methods. 77: 1-5.

Ding, C. and Zhang, D. (2007): Molecular analysis of DVH type 1. Virology. 361: 9-17.

Erfan AM.; Abdullah A. Selim; Mohamed K. Moursi; Soad A. Nasef and Abdelwhab, E.M. (2015): Epidemiology and molecular characterisation of duck hepatitis A virus from different duck breeds in Egypt. J. Vet. Micro 177: 347-352.

Fu, Y.; Pan, M.; Wang, W.; Xu, Y.; Xie, X.; Knowles, N.J.; Yang, H. and Zhang. D. (2009): Complete sequence of a duck astrovirus associated with fatal hepatitis in ducklings. $J$. Gen. Virol. 90: 1104-1108.

Fu, Y.; Pan, M.; Wang, X.; Xu, Y.; Yang, H. and Zhang, D. (2008): Molecular detection and typing of duck hepatitis A virus directlyfrom clinical specimens. Vet Microbiol. 131: 247257.

Gough, RE. and McNulty, MS. (2008): In Poult. Dis. PP. 350-357. Edited by Pattison, McMulin, Broadbury and Alexander. Saunders ElSevier.

Gough, R.E. and Stuart, J.C. (1993): Astroviruses in ducks (duck virus hepatitis type II). In: Virus Infections of Birds, Vol. 4, J. B. McFerran and M.S. McNulty, eds. Elsevier Science Publishers, B.V., Amsterdam. 505-508.

Gough, R.E. and Wallis, A.S. (1986): Duck hepatitis type I and influenza in mallard ducks (Anas platyrhynchos). Vet Rec. 119: 602.

Gough, R.E.; Borland, E.D.; Keymer, I.F. and Stuart, J.C. (1985): An outbreak of duck hepatitis type II in commercial ducks.Avian Pathol. 14: 227-236.

Gough, R.E.; Collins, M.S.; Borland, E. and Keymer, L.F. (1984): Astrovirus-like particles associated with hepatitis in ducklings. Vet Rec. 114: 279.

Haider, S.A. and Calnek, B.W. (1979): In vitro isolation, propagation, and characterization of duck hepatitis virus type III. AvianDis. 23: 715-729.

Hall, T. (1999): BioEdit: a user-friendly biological sequence alignment editor and analysis program for Windows 95/98/NT. Nucleic Acids Symp. Ser. 41, 95-98.

Hanaa, AS.; Laila, AT.; Ekram, S. and Afaf, AK. (2013): Molecular Characterization of Circulating Duck Viral Enteritis in Egypt During 2012-2013. British Journal of Poultry Science 2 (3): 38-44.

Kim, M.C.; Kwon, Y.K.; Joh, S.J.; Kim, S.J.; Tolf, C.; Kim, J.H.; Sung, H.W.; Lindberg, A.M. and Kwon, J.H. (2007): Recent Korean isolates of duck hepatitis virus reveal the presence of a new geno- and serotype when compared to duck hepatitis virus type 1 type strains. Arch. Virol. 152, 2059-2072.

Kim, M.C.; Kwon, Y.K.; Joh, S.J.; Lindberg, A.M.; Kwon, J.H.; Kim, J.H. and Kim, S.J. (2006): Molecular analysis of DVH - 1 reveals a novel lineage close to the genus Parechovirus in the family Picornaviridae. J. Gen. Virol. 87, 33073316.

Levine, P.P. and Fabricant, J. (1950): A hithertoundescribed virus disease of ducks in North America. Cornell Vet. 40: 71-86

Liu, G.; Wang, F.; Ni, Z.; Yun, T.; Yu, B.; Huang, J. and Chen, J. (2008): Genetic diversity of the VP1 gene of (DHV-I) isolates from southeast China is related to isolate attenuation. Virus Res. 137, 137-141.

Maiboroda, A.D. (1972): Formation of DVH in culture cells. Veterinariia. 48: 50-52.

Monroe, S.S.; Carter, M.J.; Herrmann, J.; Mitchel, D.K. and Sanchez-Fauquier, A. (2005): 
Family Astroviridae. In: VirusTaxonomy, Eighth Report of the International Committee on Taxonomy of Viruses, C.M. Fauquet, M.A. Mayo, J. Maniloff, U. Desselberger, and L.A. Ball, eds. Elsevier Academic Press, London. 859-864.

OIE, (2010): Duck Virus Hepatitis. OIE Terrestrial Manual 2010. (Chapter 2.3.8), available online at: http://www.oie.int/fileadmin/Home/eng/ Health_standards/tahm/2.03.08_DVH.pdf.

Reus, U. (1959): Virusbiologische untersuchungen bei der Entenhepatitis. Zentralbl Veterinaermed. 6: 209-248.

Richter, W.R.; Rozok, E.J. and Moize, S.M. (1964): Electron microscopy of virus-like particles associated with duck viral hepatitis. Virology. 24: 114-116.

Sultan, H.A. and Talaat, S.M (2014): Isolation and molecular characterization of Duck viral hepatitis disease virus in Egypt Submitted (24NOV-2014) Birds and Rabbit Dis. Dept. Fac. Vet. Med. Univ. Sadat City, Area No. 1 Sadat, Menoufiya 32511, Egypt).

Tamura, K.; Stecher, G.; Peterson, D.; Filipski, A. and Kumar, S. (2013): MEGA6: molecular evolutionary genetics analysis version 6.0. Mol. Biol. Evol. 30, 2725-2729.

Tauraso, N.M.; Coghill, G.E. and Klutch, M.J. (1969): Properties of the attenuated vaccine strain of duck hepatitis virus. Avian Dis. 13: 321-329.

Todd, D.; Smyth, V.J.; Ball, N.W.; Donnelly, B.M.; Wylie, M.; Knowles, C.H. and Adair, B.M. (2009): Identification of chicken enteroviruslike viruses, DHV- 2 and DVH-3 as astroviruses. Avian Pathol. 38: 21-30.
Toth, T.E. (1969): Studies of an agent causing mortality among ducklings immune to duck virus hepatitis. Avian Dis. 13: 834-846.

Tseng, C.H. and Tsai, H.J. (2007): Molecular characterization of a new serotype of DHV. Virus Res. 126: 19-31

Vertinskii, K.I.; Bessarabov, B.F.; Kurilenko, A.N.; Strelnikov, A.P. and Makhno, P.M. (1968): Pathogensis and diagnosis of DVH. Veterinariia. 7: 27-30.

Wei, C.Y.; Su, S.; Huang, Z.; Zhu, W.J.; Chen, J.D.; Zhao, F.R.; Wang, Y.J.; Xie, J.X.; Wang, H. and Zhang, G. (2012): Complete genome sequence of a novel DHAV discovered in southern China. J. Virol. 86, 10247.

Woolcock, P.R. (2003): Viral infections of waterfowl. In: Saif, Y.M., Barnes, H.J., Glisson, J.R., Fadly, A.M., McDougald, L.R. (Eds.), Diseases of Poultry. Iowa State Press, Ames, IA, USA, p. 1248.

Woolcock, P. (2010): DVH. In: Manual of Diagnostic Tests and Vaccines for Terrestrial Animals. Office International des Epizooties, Paris, France.

Woolcock, P.R. (2008): Duck hepatitis. In: A Laboratory Manual for the Isolation, Identification and Characterization of Avian Pathogens, 5th ed. L. Dufour-Zavala, D.E. Swayne, J.R. Glisson, J.E. Pearson, W.M. Reed, M.W. Jackwood, and P.R. Woolcock, eds. AAAP, Jacksonville, FL. 175-178.

Woolcoock, PR. And Tsai, HH. (2013): In Dis. Of Poult. $13^{\text {th }}$ ed. Pp. 422-431. Edited by D E. Swayne, J R. Glisson, L R. McDougald, L K. Nolan, D L. Suarez and V. Nair.

\section{الوصف الجزيئي لمعزولة التهاب كبدي فيروسي من البط بمحافظة الثرقية}

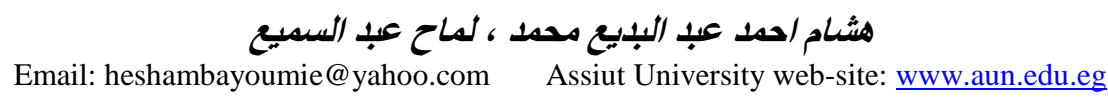

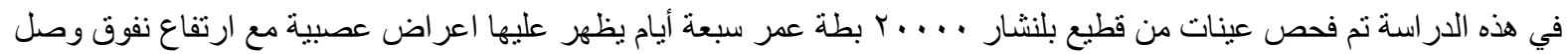

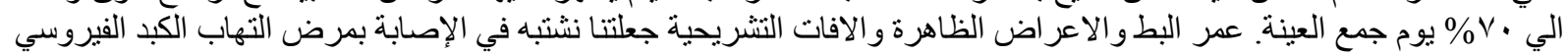

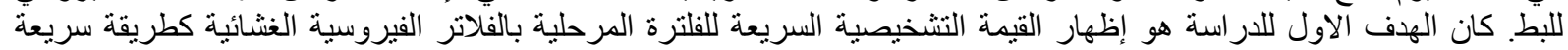
فعالة لتشخيص مرض التهاب الكبد الفيروسي لخصائص الفيروس الذي ينتمي الي عائلة Picornaviridae وتم مقارنة نتائج هذا

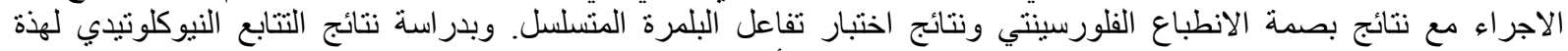

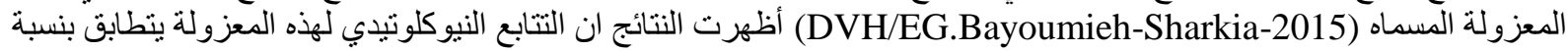

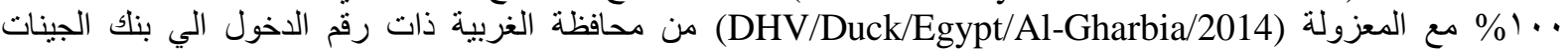
(KP202874) و التي تم عزلها دونما نشربمعرفة (قسم امر اض الطيور و الار انب بكلية الطب البيطري جامعة السادات ـ المنوفية) (3D protein gene fragment) وان هذه المعزولة كانت تنشابه

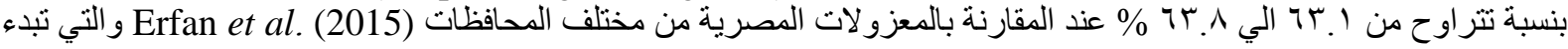

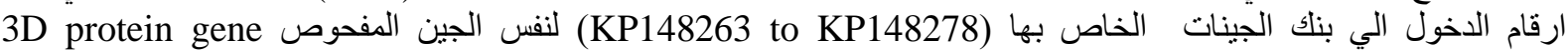
fragment. 